\title{
Solar convective drying kinetics and sorption isotherms of Citrus aurantium flowers
}

\author{
El Ferouali, H.; Zoukit, A.; Doubabi, S.; Abdenouri, N.* \\ LSET, Cadi Ayyad University, Marrakech, Morocco. \\ Cadi Ayyad University, Marrakech, Morocco. \\ *E-mail of the corresponding author: n.abdenouri@uca.ma
}

\begin{abstract}
Citrus aurantium flowers are high value aromatic and medicinal plants. The storage conditions and quality of dried Citrus aurantium flowers depends on their hygroscopic stability. The equilibrium moisture content was determined at temperatures (from 30 to $60{ }^{\circ} \mathrm{C}$ ), and the sorption phenomenon is well described by Peleg model. The optimal water activity for the storage of the product was estimated at $a_{\text {wop }}=0.373$. Afterwards, the net isosteric heat was

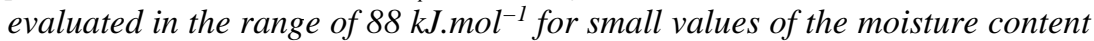
$\left(X_{e q}=0.14 \mathrm{~kg}\right.$ water $\left./ \mathrm{kg} d . b\right)$, and it decreased along with the increase of $X_{\text {eq. }}$. The experimental drying curves showed only a falling rate period. Finally, Midilli-Kucuk model was found to be the more suitable to describe the drying kinetic of Citrus aurantium flowers.
\end{abstract}

Keywords: Drying kinetics; Solar energy; Modeling; Citrus aurantium; Sorption isotherms; Conservation process. 


\section{Introduction}

Medicinal and aromatic plants have a crucial value in the pharmaceutical industry and traditional medicine. Drying is the most used preservation operation in the storage of medicinal and aromatic plants and it is a part of the extraction process of high value substances. The indirect solar drying is more adapted to developing countries; it is economic, fast and leads to a homogeneous and edible product [1].

Citrus aurantium flowers are known for their benefits on nervous balance and digestion [2]. They are often used for the extraction of the main assets. These flowers are very rich in essential oil that can be used in the composition of some perfumes. For the natural medicine, the leaf is used for its sedative and soothing properties. Indeed its essential oil, associated with other bitter principles gives him soothing and relaxing properties. Furthermore, they are usually prescribed to regulate mild sleep disorders and to treat nervousness. In this case, the preservation of this material by drying and the establishment of desorption isotherms are very useful for its conservation [3].

The sorption isotherms are a good way to describe how active water is bound to a wet product [4]. They are also an extremely valuable tool because it provides precious information about the hygroscopic equilibrium [5]. In other words, it is necessary to determine the optimum moisture content and the water activity that must be achieved during drying for better preservation of the dried product.

Only experimental studies allow determining the drying kinetics of products. Therefore, it is interesting to study variations of moisture content for different controllable aerothermal parameters. The mechanisms of these transfers are very complex and they lead to large physical, chemical and biological changes. Hence, the evolution of these parameters must be controlled in order to achieve the best quality [6,7].

The main objectives of this study are:

- To determine the effect of temperature on the moisture desorption and adsorption isotherms of Citrus aurantium flowers, and to find the appropriate model that describes its sorption curves.

- To determine the optimal storage condition of the product and the isosteric heat of sorption.

- To investigate the drying kinetics of Citrus aurantium flowers.

\section{Materials and Methods}

\subsection{Sorption isotherms}


The hygroscopic equilibrium was achieved by the static gravimetric technique [8]. The samples that were used for desorption were fresh and weighed around $1 \pm 0.1 \mathrm{~g}$. The ones that were used for adsorption had been dried for $24 \mathrm{~h}$ in an oven at $105^{\circ} \mathrm{C}$ before putting them on the glass jars; their weight was around $0.1 \pm 0.01 \mathrm{~g}$. This process was performed at three different temperatures $\left(30,40\right.$ and $\left.50{ }^{\circ} \mathrm{C}\right)$.

\subsection{Description of the solar drying}

The experimental apparatus consists of an indirect forced convection solar dryer. The solar dryer was described in detail in [9]. The same mass of fresh Citrus aurantium flowers $(20 \pm 1 \mathrm{~g})$ was used for each drying experiment. Drying experiments were performed for three temperatures $\left(40,50\right.$ and $\left.60{ }^{\circ} \mathrm{C}\right)$ with the air flow rate of $0.083 \mathrm{~m}^{3} \cdot \mathrm{s}^{-1}$.

\section{Results}

\subsection{Desorption and adsorption isotherms}

Figs. 1 and 2 show the effect of temperature on desorption and adsorption of Citrus aurantium flowers. Xeq increases by decreasing temperature at constant water activity. This result may be explained by the higher excitation state of water molecules at higher temperature thus decreasing the attractive forces between them [10]. The sorption isotherms are type II of the IUPAC classification and exhibit a sigmoidal shape; this is consistent with the behavior of other medicinal and aromatic plants [11]. In the present study, the relationship between $X e q$ and $a_{w}$ at 30,40 and $50{ }^{\circ} \mathrm{C}$ was predicted by applying mathematical models. The used models' equations (GAB, Modified Henderson, Modified Halsey, Modified Oswin , Enderby and Peleg) are given in [12]. The best model, describing sorption isotherms of the product, has the highest value of the correlation coefficient $r$ and smallest values of SEM and MRE. These statistical errors are defined respectively by Eqs. (1) and (2):

$$
\begin{gathered}
S E M=\sqrt{\frac{\sum_{i=1}^{N}\left(X e q_{i, p r e}-X e q_{i, \exp }\right)^{2}}{d_{f}}} \\
M R E=\frac{100}{N} \sum_{i=1}^{N}\left|\frac{X e q_{i, p r e}-X e q_{i, \exp }}{X e q_{i, \exp }}\right|
\end{gathered}
$$

Where Xeqi,exp is the ith experimental moisture content, Xeqi,pre is the ith predicted moisture content, and $d_{f}$ is the freedom degree of the regression model. The Peleg model gives the best fitting to the experimental data with a correlation coefficient $r$ of 0.9847 and 0.9920 , SEM of 1.0856 and 1.0562, and MRE of $9.3654 \%$ and $10.1268 \%$ respectively for desorption and adsorption isotherms. 


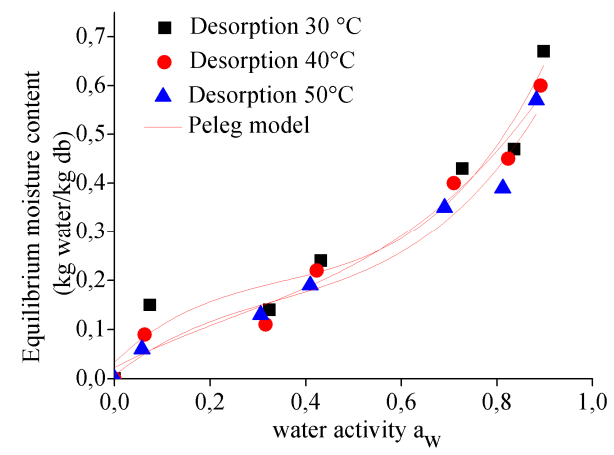

Fig. 1 Desorption isotherms of Citrus aurantium flowers at 30, 40 and $50{ }^{\circ} \mathrm{C}$.

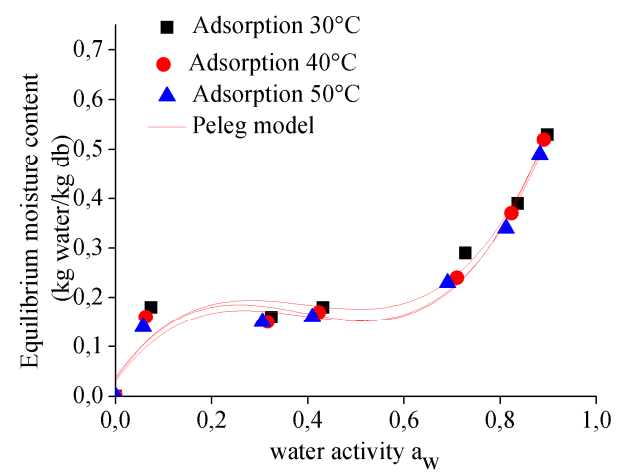

Fig. 2 Adsorption isotherms of Citrus aurantium flowers at 30, 40 and $50{ }^{\circ} \mathrm{C}$.

\subsection{Determination of the optimum conditions for the storage}

All experimental data of desorption and adsorption at 30,40 and $50^{\circ} \mathrm{C}$ were gathered on the same graph (Fig. 3). This curve allowed to determine the value at which the second derivative of $X e q$ equals to zero and consequently the optimum value of water activity for storage. The found value for Citrus aurantium flowers $\left(a_{w o p}=0.373\right)$ is in agreement with the general stability domain of biological products that is between 0.2 and 0.4 [13].

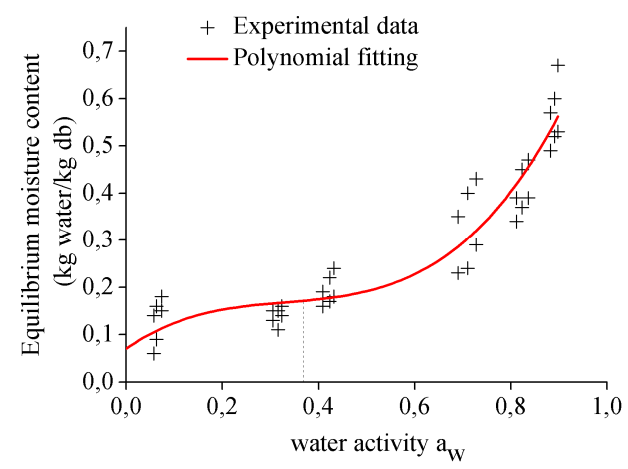

Fig. 3. Determination of the optimal water activity for storage of Citrus aurantium flowers. 


\subsection{Net isosteric heat}

The net isosteric heat of sorption was calculated from the experimental data using the Clausius Clapeyron equation given by Eq. (3):

$$
\left[\frac{d\left(\ln a_{w}\right)}{d(1 / T)}\right]_{X_{e q}}=\frac{-\Delta h_{d}}{R}
$$

Fig. 4 presents the isosteric heat of sorption of Citrus aurantium flowers at temperatures ranging between $30{ }^{\circ} \mathrm{C}$ and $50{ }^{\circ} \mathrm{C}$. This curves show that the isosteric heat is higher for small values of the moisture content $\left(88 \mathrm{~kJ} \cdot \mathrm{mol}^{-1}\right.$ for $X_{e q}=0.14 \mathrm{~kg}$ water $\left./ \mathrm{kg} \mathrm{d} . \mathrm{b}\right)$ indicating the highest binding energy for water removal, and it decreased along with the increase of the Xeq [14].

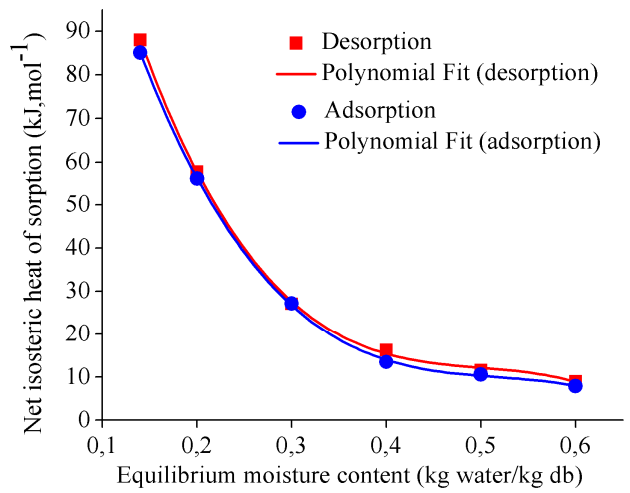

Fig. 4. Net isosteric heat of desorption and adsorption of Citrus aurantium flowers versus equilibrium moisture content.

\subsection{Drying kinetics of Citrus aurantium flowers}

An increase in the drying air temperature had led to a significant reduction in the drying time; from $340 \mathrm{~min}$ for a temperature of $40{ }^{\circ} \mathrm{C}$ to $220 \mathrm{~min}$ for a temperature of $60{ }^{\circ} \mathrm{C}$ (Fig. 5). It can be noticed the presence of only the falling drying rate period (phase 2) which is governed by the water diffusion in the material [15].

Several mathematical models are used to describe the macroscopic behavior of the products. In this work, the most models describing drying kinetics were used: Newton, Page, Henderson and Pabis, Logarithmic, Two term, Two term exponential, Wang and Singh, Diffusion approach, Verma et al. and Midilli-Kucuk. The models' expressions are given in literature [16]. The moisture ratio of Citrus aurantium flowers during the thin layer drying experiments was calculated by using Eq. (4):

$$
X^{*}=\frac{X-X_{e q}}{X_{0}-X_{e q}}
$$


The appropriate model was selected according to the highest correlation coefficient $(r)$, the lowest $M B E$ (Eq. (5))and the lowest $\chi^{2}$.

$$
M B E=\frac{1}{N} \sum_{i=1}^{N}\left(X_{\text {pre }, i}^{*}-X_{\text {exp }, i}^{*}\right)
$$

Where $X^{*}$ exp, $i$ stands for the experimental moisture ratio found in the measurements; $X^{*}$ pre,$i$ is the predicted moisture ratio for this measurement.

Midilli-Kucuk model was selected as the most convenient model to represent the drying behavior of Citrus aurantium flowers with $R, \chi^{2}$ and $M B E$ respectively of $0.9991,0.00037$ and 0.00017 . These result highlighted the ability of this model to better simulate the change in water content in the solar drying Citrus aurantium flowers. Hence, this product presents a weak external resistance to heat and mass transfer [17].

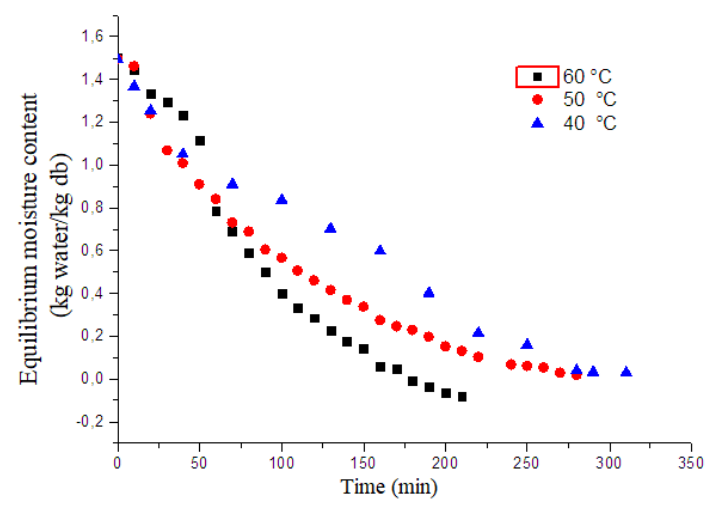

Fig. 5. Variation of moisture content as a function of time.

\section{Conclusions}

The storage conditions and the quality of dried Citrus aurantium flowers depend to a great extent on their hygroscopic stability. Hence, the equilibrium moisture content was investigated at three temperatures in the most convenient range for plants (from 30 to 60 $\left.{ }^{\circ} \mathrm{C}\right)$. The sorption phenomenon is well described by the semi-empirical Peleg model. The optimal water activity for the storage of the product was estimated at $a_{w o p}=0.373$. Then, the net isosteric heat of sorption of the samples was computed from the predicted sorption data. It was evaluated in the range of $88 \mathrm{~kJ} \cdot \mathrm{mol}^{-1}$ for small values of the moisture content $(X e q=0.14 \mathrm{~kg}$ water $/ \mathrm{kg} \mathrm{db})$, and it decreased along with the increase of the Xeq; this thermodynamic quantity estimates the required energy for dehydration processes. Drying experiences were conducted in Marrakech (Morocco) by using an indirect forced convection solar dryer at three temperatures $\left(40,50\right.$ and $\left.60^{\circ} \mathrm{C}\right)$. The experimental drying curves showed only a falling rate period. Finally, Midilli-Kucuk model was found to be the more suitable to describe the drying kinetic of Citrus aurantium flowers. 


\section{Nomenclature}

$\begin{array}{lll}M_{d} & \text { Mass of dry matter } & \mathrm{kg} \\ M_{e q} & \text { Mass at the hygroscopic equilibrium } & \mathrm{kg} \\ X & \text { Moisture content at any time during drying } & (\mathrm{kg} \text { water } / \mathrm{kg} \mathrm{db}) \\ X_{0} & \text { Initial moisture content } & (\mathrm{kg} \mathrm{water} / \mathrm{kg} \mathrm{db}) \\ X_{e q} & \text { Equilibrium moisture content } & (\mathrm{kg} \mathrm{water} / \mathrm{kg} \mathrm{db}) \\ X^{*} & \text { Moisture ratio } & \\ a_{w} & \text { Water activity } & \\ r & \text { Correlation coefficient } & \\ S E M & \text { Standard Error of Moisture } & \\ M R E & \text { Mean Relative Error } & \% \\ M B E & \text { Mean bias error } & \\ \Delta h_{d} & \text { Net isosteric heat of sorption } & \mathrm{kJ} \cdot \mathrm{mol}^{-1} \\ \Delta H_{v a p} & \text { Heat of vaporization of pure water at } 35^{\circ} \mathrm{C} & 43.53 \mathrm{~kJ} \cdot \mathrm{mol}^{-1} \\ R & \text { Universal gas constant } & 8.3145 \mathrm{~J} \cdot \mathrm{mol}^{-1} \cdot \mathrm{K}^{-1}\end{array}$

Greek letters

$\chi^{2} \quad$ Reduced chi-square

\section{Acknowledgements}

This work was supported by the research institute IRESEN and all of the authors are grateful to the IRESEN for its cooperation.

\section{References}

[1] Doymaz, I. Drying behaviour of green beans. Journal of Food Engineering 2005, 69, 161-165.

[2] www.alchimiste.fr, 2008.

[3] Aït Mohamed, L. Etude Physico-chimique de la Qualité et de la Conservation Avant et Après Séchage Convectif Solaire du Gelidium sesquipedale (Algue Rouge) et du Citrus aurantium (Orange Amer)', Thèse de Doctorat, Université Cadi Ayyad, Marrakech, Maroc, 2006.

[4] Abdenouri, N; Idlimam, A.;Kouhila, M. Sorption Isotherms and Thermodynamic Properties of Powdered Milk. Chemical Engineering Communications 2010., 197(8), 1109-1125. 
[5] Zhao, P.; Zhong, L.; Zhao, Y.; Luo, Z.. Comparative studies on the effect of mineral matter on physico-chemical properties, inherent moisture and drying kinetics of Chinese lignite. Energy Conversion and Management 2015, 93, 197-204.

[6] El Ferouali, H. ; Zehhar, N. ; et al. EFFECT OF DRYING TECHNIQUES PROCESS ON NUTRITIONAL AND BIOCHEMICAL QUALITY OF GREEN BEANS.In Second Nordic Baltic Drying Conference. Hamburg, Germany, 2017.

[7] El Ferouali, H., Zehhar, N., et al. STUDY OF THE EFFECT OF DIFFFRENT DRYING TECHNIQUES ON NUTRITIONAL QUALITY OF TOMATO SOLANUM LYCOPERSICUM L.. In 6th European drying conference Eurodrying. Liege, Belgium, 2017.

[8] Greenspan, L. Humidity fixed points of binary saturated aqueous solutions, Journal of research of the national bureau of standards 1977, 81(1), 89-96.

[9] El Ferouali, H. et al. CFD study of a designed forced convection solar dryer. application to the drying of punica granatum legrelliae's flowers, in The 20th International Drying Symposium, Gifu, JAPAN, 2016.

[10] Goneli, A. L. D.; Corrêa, P. C.; Oliveira, G. D.; Júnior, P. A. Water sorption properties of coffee fruits, pulped and green coffee. LWT-Food Science and Technology 2013, 50(2), 386-391.

[11] Mujumdar, A. S. Handbook of Industrial Drying. New York: Ed. Marcel Dekker Inc., 2006.

[12] Basu, S.; Shivhare, U. S.; Mujumdar, A. S. Models for Sorption Isotherms for Foods: A Review, Drying technology 2006, 24(8), 917-930.

[13] LE Meste, M.; ROUdAut, G. ; Chiotelli, E. ; Simatos, D. ; COLAS, B. Propriétés fonctionnelles de l'eau dans les aliments: Dossier eau. Industries alimentaires et agricoles 2001, 118(5), 21-28.

[14] Brunauer, S.; Deming, L. S.; Teller, E. On a Theory of the van der Waals Adsorption of Gases, Journal of the American Chemical Society 1940. 62(7),1723-1732.

[15] Al hodali, R.; Bougard, J. Numerical simulation of an agricultural foodstuffs drying unit using solar energy and adsorption process. Université Libre de Bruxelles, Belgium, 1977.

[16] Menges, H. O.; Ertekin, C. Mathematical modeling of thin layer drying of Golden apples. Journal of Food Engineering 2006, 77(1), 119-125.

[17] Midilli, A.; Kucuk, H.; Yapar, Z. A new model for single-layer drying. Drying technology 2002, 20(7), 1503-1513. 